九州大学学術情報リポジトリ

Kyushu University Institutional Repository

\title{
Immobilization of Lactococcus lactis $10-1$ for Nisin Z Production
}

Chinachoti, Noppawan

Sonomoto, Kenj i

Laboratory of Microbial Technology, Department of Food Science and Technology, Faculty of Agriculture, Kyushu University

Ishizaki, Ayaaki

Laboratory of Microbial Technology, Department of Food Science and Technology, Faculty of Agriculture, Kyushu University

https://doi.org/10.5109/24203

出版情報：九州大学大学院農学研究院紀要. 42 (1/2)，pp.151-169，1997-12. Kyushu University バージョン：

権利関係 : 


\title{
Immobilization of Lactococcus lactis IO-1 for Nisin Z Production
}

\author{
Noppawan Chinachoti, Kenji Sonomoto and Ayaaki Ishizaki \\ Laboratory of Microbial Technology, Department of Food Science and Technology, \\ Faculty of Agriculture, Kyushu University, \\ 6-10-1 Hakozaki, Higashi-ku, Fukuoka 812-81, Japan \\ (Received July 30, 1997 and accepted August 25, 1997)
}

\begin{abstract}
The immobilization technique was applied to improve the productivity of nisin $\mathrm{Z}$, the peptide antibiotic produced by Lactococcus lactis IO-1. Both entrapment and adsorption methods of immobilization were studied with several kinds of materials in repeated fermentation. The long-term application of natural materials was limited because of the instability of the gel. Low growth rate and low productivity were obtained from the entrapment method due to the improper diffusion of nutrients through the materials. Moreover, the method to entrap the cells with photo-crosslinkable resin prepolymers caused damage to the cells. The adsorption method showed better results compared with the entrapment method. The adsorption of the cells on porous chitosan beads, Chitopearl SH-2510, gave nisin Z productivity about 1.7 times greater than the free cells. However, during the repeated cultivation a decrease in nisin $Z$ activity was observed. The cells adsorbed on photo-crosslinked resin gel beads, ENTG-3800, produced a greater amount of nisin $Z$ and a lower level of lactate than the free cells with a good operational stability. The nisin $Z$ production tended to increase with repeated cultivation.
\end{abstract}

\section{INTRODUCTION}

Nisin has attracted extensive interest in recent years due to its activity against various food-borne pathogens (Araya et al., 1992). For potent commercial application, the higher yields are often required; thus, a varieties of growth conditions and medium composition have been investigated to optimize the production (de Vuyst and Vandamme, 1992 ; 1993; de Vuyst, 1994). Normally, a nisin activity level of around $2000 \mathrm{IU} / \mathrm{ml}$ was obtained from synthetic media (de Vuyst and Vandamme, 1993). Greater nisin yield was reported from complex media than from synthetic media. However, the use of synthetic media implies an extended knowledge about the effect of specific nutritional factors on growth and production. Moreover, an appropriate environment for an easy and efficient downstream process was obtained with synthetic media (de Vuyst, 1994). The recovery of cells after fermentation can be tedious, inefficient and costly when using traditional processes such as centrifugation. The immobilization technique was introduced to facilitate the separation of cells from products in a fermentation broth. Cell immobilization also leads to greater productivity as a result of the confinement of high cell density in the reactor. The long-term operational stability of the bioreactors can be expected with immobilized cells. Furthermore, the immobilization system can be applied to diminish cell washout in continuous fermentation; thus, the reactor could be operated at higher dilution rate (Huang et al., 1996).

The immobilization technique was first carried out with enzyme early in the twentieth century (Chibata, 1978). Recently the immobilized cell technique has been widely used 
in applications such as in a brewery (Yamauchi et al., 1994), ethanol production (Iida et al., 1993a, b; Ogbonna et al., 1994), acid production (Nomura et al., 1987; Boyaval and Goulet, 1988; Cachon et al., 1995; Yang and Huang, 1995; Mehaia and Cheryan, 1987), amino acid production (Tanaka et al., 1989) and waste treatment (Uchiyama et al., 1994). Takashima et al. (1987) reported the production of daunorubicin by Streptomyces peucetius cells immobilized with calcium alginate and photosensitive resin prepolymer. Recently, the immobilization of lactic acid bacteria for the production of bacteriocin was studied. Zezza et al. (1993) tried to produce nisin by Lactococcus lactis subsp. lactis NZ1 immobilized in coated alginate beads. Wan et al. (1995) studied the continuous production of brevicin, nisin, and pediocin using calcium alginate-immobilized bacteria. Pasini et al. (1995) immobilized Lactococcus lactis subsp. lactis NZ1 with barium alginate beads to produce nisin in milk, Huang et al. (1996) produced pediocin 5 continuously by immobilized Pediococcus acidilactici UL5 cultures, and Cho et al. (1996) studied pediocin production by a packed-bed bioreactor with immobilized Pediococcus acidilactici $\mathrm{PO} 2$ cells.

Immobilization is roughly grouped into three methods, namely, carrier-binding method, cross-linking method, and entrapping method. In practice, the applications of cells entrapped in polymer gels such as calcium alginate and $\kappa$-carrageenan were limited due to gel instability (Ogbonna et al., 1989) and the limitation of nutrient transfer within the gel (Tanaka et al., 1984). Sloughing of the excess cells from the supports that leads to low cell concentration and low productivity was found in immobilization with the adsorption method (Mori et al., 1992).

Recently, continuous attempts have been made to find new materials and techniques for gel formation that avoid unfavorable effects and develop more convenient immobilization procedures. For these purposes, novel materials such as urethane prepolymer (Fukui et al., 1987), photo-crosslinkable resin prepolymer (Fukui et al., 1987), and porous chitosan beads (Mori et al., 1992) that cause less harmful effect on the immobilized cells were introduced. These immobilization procedures can be achieved without heating, shifting to extreme $\mathrm{pH}$ value, or using harmful chemicals.

In the present paper, the production of nisin $\mathrm{Z}$ was studied by Lactococcus lactis IO1, a nisin-producing strain isolated in our laboratory (Ishizaki et al., 1990; Matsusaki et al., 1996b), immobilized with various kinds of materials in both the entrapment and adsorption methods in order to select the most suitable material and procedure.

\section{MATERIALS AND METHODS}

\section{Natural materials for cell immobilization}

Agar and sodium alginate were obtained from Nacalai Tesque, Inc. (Kyoto, Japan), agarose type VI was purchased from Sigma Chemical Co. (St. Louis, Miss., USA) and $\kappa$ carrageenan was from Tanabe Seiyaku, Ltd. (Osaka, Japan).

\section{Synthetic and chemically modified materials for cell immobilization}

Urethane prepolymers (PU-3 and PU-6) were products of Toyo Tire and Rubber Co. (Osaka, Japan). These prepolymers are synthesized from toluene dissocyanate and polyether diol moiety (chain length, ca. 25-26 nm) that are composed of polyethylene 
glycol and polypropylene glycol (Fukui et al., 1987). PU-3 is hydrophobic because of high polypropylene glycol content (43\%), and PU-6 is hydrophilic (polypropylene glycol, 9\%).

Photo-crosslinkable resin prepolymers and photo-crosslinked resin beads were synthesized by Kansai Paint Co. (Tokyo, Japan). The photo-crosslinkable resin prepolymers (Fukui et al., 1987; Iida, 1992) used in this experiment are shown in Table 1.

Photo-crosslinked resin beads (ENT-2000, VGE-112 and ENTG-3800) were prepared as follows (Iida, 1994): For bead forming, 3\% sodium alginate was mixed with each photocrosslinkable resin prepolymer together with a photo-initiator, and gel beads were formed by dropping the mixture into $2 \% \mathrm{CaCl}_{2}$ solution. VGE-112 beads were prepared using the prepolymer (chain length, ca. $25 \mathrm{~nm}$ ) whose main chain was polyethylene glycol, polyvinyl alcohol and polypropylene glycol $(39: 4: 7 \mathrm{w} / \mathrm{w})$. The beads thus formed were irradiated for $5 \mathrm{~min}$ by near-ultraviolet light at $300-400 \mathrm{~nm}$. After the irradiation, the beads were washed twice with tap water. The beads with a diameter of $c a .4 \mathrm{~mm}$ showed a compressive strength of $15-25 \mathrm{~kg} / \mathrm{cm}^{2}$. Their hydrophilicity decreases in order of ENT2000, VGE-112, and ENTG-3800.

Porous chitosan beads (Chitopearl) (Mori et al., 1992) were supported by Fuji Spinning Co., Ltd. (Tokyo, Japan) (Table 2).

Table 1. Properties of photo-crosslinkable resin prepolymer

\begin{tabular}{llcl}
\hline Prepolymer & Main chain & $\begin{array}{c}\text { Chain length } \\
\text { (nm) }\end{array}$ & Property \\
\hline ENT-3400 & Polyethylene glycol & 34 & Hydrophilic \\
ENTG-3800 & $\begin{array}{c}\text { Polyethylene glycol } \\
\text { mixed with } \\
\text { polypropylene glycol } \\
(4: 1 \text { w/w) }\end{array}$ & 38 & Hydrophilic \\
& Polypropylene glycol & 40 & Hydrophobic \\
\hline
\end{tabular}

Table 2. Properties of porous chitosan beads

\begin{tabular}{ccccc}
\hline Chitopearl & Functional group & Binding mode & $\begin{array}{c}\text { Particle size } \\
(\mathrm{mm})\end{array}$ & $\begin{array}{c}\text { Pore size } \\
(\mu \mathrm{m})\end{array}$ \\
\hline SH-2503 & Primary, secondary and & lonic & 0.3 & 5 \\
SH-2510 & quaternary amines & & 1.0 & 5 \\
HP-2520 & & & 2.0 & 50 \\
\hline HP-3020 & Primary amine and & Hydrophobic & 2.0 & 50 \\
SH-3503 & Primear alkyl & and ionic & 0.3 & 5 \\
SH-3510 & aromatic alkyl & Hydrophobic & 1.0 & 5 \\
HP-3520 & & & 2.0 & 50 \\
\hline HP-5020 & Chitin-like structure & Hydrophobic & 2.0 & 50 \\
& & and ionic & & \\
\hline
\end{tabular}




\section{Preparation of cell suspension}

Lactococcus lactis IO-1 stock culture was subcultured into $10 \mathrm{ml}$ of thioglycolate medium without glucose (Difco Laboratories, Detroit, Mich., USA). Static incubation was done at $37^{\circ} \mathrm{C}$ for $18 \mathrm{~h}$ before the culture was added into $100 \mathrm{ml}$ of $\mathrm{CM}$ medium supplemented with $1 \%$ glucose for preculture. The CM medium contained $0.5 \%$ yeast extract (Difco Laboratories, Detroit, Mich., USA), 0.5\% polypeptone (Nihon Seiyaku Co., Ltd., Tokyo, Japan) and $0.5 \% \mathrm{NaCl}$ in distilled water at $\mathrm{pH} 7.0$. The culture was incubated at $30^{\circ} \mathrm{C}$ and $320 \mathrm{rpm}$ for $3 \mathrm{~h}$. The seed culture then obtained was centrifuged at $17,800 \times$ $\mathrm{g}$ for $15 \mathrm{~min}$. The cell pellet was washed twice and resuspended with $0.85 \% \mathrm{NaCl}$ solution to obtain $6.72 \mathrm{~g}$-DCW/ $\ell$ of cell suspension. The resulting cell suspension was used for cell-entrapment as described below. Cell immobilization was aseptically performed in all the methods.

\section{Cell-entrapment method \\ 1) Calcium alginate}

Six $\mathrm{ml}$ of sodium alginate solution $(0.03 \mathrm{~g} / \mathrm{ml})$ was autoclaved at $110^{\circ} \mathrm{C}$ for $10 \mathrm{~min}$ and kept at $45^{\circ} \mathrm{C}$ until used. The cell suspension $(1.25 \mathrm{ml})$ previously described was added to the sterile sodium alginate solution. The mixture was gently mixed and quickly dropped into $50 \mathrm{ml}$ of $0.1 \mathrm{M} \mathrm{CaCl}_{2}$ solution with a No.18 syringe (Terumo Co., Ltd., Tokyo, Japan). The spherical beads (diameter, ca. $3.2-3.5 \mathrm{~mm}$ ) were obtained and kept in $\mathrm{CaCl}_{2}$ solution for $3 \mathrm{~h}$ at room temperature.

\section{2) $\kappa$-Carrageenan}

$\kappa$-Carrageenan solution $(0.07 \mathrm{~g} / \mathrm{ml})$ of $2.5 \mathrm{ml}$ was autoclaved at $110^{\circ} \mathrm{C}$ for $10 \mathrm{~min}$. The solution was quickly mixed with $1.25 \mathrm{ml}$ of cell suspension in a 50 -ml beaker at $45^{\circ} \mathrm{C}$. The mixture was left until complete gel formation at room temperature, and then the gel was soaked with sterile $0.3 \mathrm{M} \mathrm{KCl}$ solution at room temperature for $30 \mathrm{~min}$. The gel was aseptically cut into small pieces (each ca. $5 \times 5 \times 2 \mathrm{~mm}$ ).

\section{3) Agar and agarose}

Five $\mathrm{ml}$ of agar or agarose solution at a concentration of $0.03 \mathrm{~g} / \mathrm{ml}$ was autoclaved at $110^{\circ} \mathrm{C}$ for $10 \mathrm{~min}$. The cell suspension $(1.25 \mathrm{ml})$ was added into the solution kept in a 50 $\mathrm{ml}$ beaker at $45^{\circ} \mathrm{C}$. The mixtures were gently mixed and left at room temperature until the gel formation was completed. The gels were aseptically cut into pieces which have the same size as the $\kappa$-carrageenan-immobilized cells.

\section{4) Urethane prepolymer}

Two kinds of urethane prepolymers (PU-3 and PU-6) $0.625 \mathrm{~g}$ each sterilized in an oven at $160^{\circ} \mathrm{C}$ for $10 \mathrm{~min}$ were quickly mixed with $1.25 \mathrm{ml}$ of cell suspension. The mixtures stood at $4{ }^{\circ} \mathrm{C}$ for $30 \mathrm{~min}$. The gels formed were aseptically cut into small pieces of ca. $5 \times 5 \times 5 \mathrm{~mm}$.

\section{5) Photo-crosslinkable resin prepolymer}

Each of the photo-crosslikable resin prepolymers in the amount of $2.5 \mathrm{~g}$ was autoclaved at $110^{\circ} \mathrm{C}$ for $10 \mathrm{~min}$. The prepolymers were mixed with $0.02 \mathrm{~g}$ of benzoin 
isobutyl ether as a photosensitizer, $1.25 \mathrm{ml}$ of cell suspension and $0.24 \mathrm{ml}$ of $0.85 \% \mathrm{NaCl}$ solution. The mixtures were spread on the transparent glass plate and illuminated with near-ultraviolet light over the wavelength range $300-400 \mathrm{~nm}$, maximum intensity at $360 \mathrm{~nm}$, for $3 \mathrm{~min}$ as previously described (Fukui et al., 1987; Iida, 1994). Immobilization with ENTP-4000 was performed in the same manner, except benzoin isobutyl ether and $0.85 \% \mathrm{NaCl}$ solution were added in the amount of $0.05 \mathrm{~g}$ and $0.05 \mathrm{ml}$, respectively. The resin film formed (thickness, $c a .1 \mathrm{~mm}$ ) was aseptically cut into small pieces (each $c a .5 \times$ $5 \mathrm{~mm}$ ) and washed with sterile $0.85 \% \mathrm{NaCl}$ solution.

\section{Cell-adsorption method}

Five ml of porous chitosan beads or photo-crosslinked resin gel beads was autoclaved in distilled water at $110^{\circ} \mathrm{C}$ for $10 \mathrm{~min}$ before addition to $100 \mathrm{ml}$ of $\mathrm{CM}$ medium supplemented with $4 \%$ glucose and $2 \% \mathrm{CaCO}_{3}$. Five percent of the seed culture was then added and the culture was incubated at $30^{\circ} \mathrm{C}$ and 120 strokes/min for $16 \mathrm{~h}$. The celladsorbed gel beads obtained were washed with sterile distilled water before use as immobilized cells.

\section{Repeated batch cultivation}

\section{1) Free cells}

Five $\mathrm{ml}$ of the seed culture was inoculated to $100 \mathrm{ml}$ of $\mathrm{CM}$ medium supplemented with $40 \mathrm{~g} / l$ of glucose and $20 \mathrm{~g} / \mathrm{l}$ of $\mathrm{CaCO}_{3}$. The culture was incubated at $30^{\circ} \mathrm{C}$ with shaking at 100 strokes/min. Five $\mathrm{ml}$ of the culture was withdrawn and transferred to a fresh medium every $24 \mathrm{~h}$.

\section{2) Entrapped cells}

Each type of immobilized cell was inoculated into $100 \mathrm{ml}$ of $\mathrm{CM}$ medium supplemented with $50 \mathrm{~g} / l$ of glucose and $25 \mathrm{~g} / l$ of $\mathrm{CaCO}_{3}$. The culture was incubated at $30^{\circ} \mathrm{C}$ and 100 strokes/min. After incubation for $24 \mathrm{~h}$, the immobilized cells were washed with sterile $0.85 \% \mathrm{NaCl}$ solution and were employed in the ten successive batches of cultivation.

\section{3) Adsorbed cells}

Each type of immobilized bead was inoculated into $100 \mathrm{ml}$ of $\mathrm{CM}$ medium supplemented with $40 \mathrm{~g} / \mathrm{l}$ glucose and $20 \mathrm{~g} / \mathrm{l} \mathrm{CaCO}_{3}$. The cultures were incubated at $30^{\circ} \mathrm{C}$ and 100 strokes/min. Repeated batch cultivation was performed as in the case of the entrapped cells.

\section{Analytical methods}

All samples were analysed for the residual glucose and the produced lactate by a glucose-lactate analyzer (model 23A-23L, Yellow Spring International Co., Ltd., Ohio, USA) and for dry cell weight (DCW) by conversion from optical absorbance at $562 \mathrm{~nm}$ with a spectrophotometer (Uvidec 320, Japan Spectroscopic, Tokyo, Japan). Nisin Z produced was determined by reversed-phase high-performance liquid chromatography as described in our previous reports (Matsusaki et al., 1996a, b). One unit of nisin Z activity is defined as an arbitary unit (AU) of activity that is equivalent to the activity of $1 \mu \mathrm{g}$ of 
commercial nisin (ICN Biomedicals, Inc., Costa Mesa, Cal., USA; activity, $1000 \mathrm{IU} / \mathrm{mg}$ solid; nisin content, $2.5 \%)$.

\section{Cell-adsorption and desorption of gel beads}

\section{1) Cell adsorption}

The seed culture of $L$. lactis IO-1 was prepared as stated above. Five ml of the seed culture was inoculated into $100 \mathrm{ml}$ of $\mathrm{CM}$ medium containing $1 \%$ glucose, and the culture was incubated at $37^{\circ} \mathrm{C}$ and 100 strokes/min for $12 \mathrm{~h}$. L. lactis IO-1 cells were harvested by centrifugation and suspended in $100 \mathrm{ml}$ distilled water. Ten $\mathrm{ml}$ of gel beads was added to the cell suspension. The cell suspension was incubated at $30^{\circ} \mathrm{C}$ or $37^{\circ} \mathrm{C}$ at $100 \mathrm{rpm}$. The decrease in the absorbance of the cell suspension at $562 \mathrm{~nm}$ was measured. Each cell mass adsorbed on chitosan gel beads was calculated as follows:

$$
\text { Adsorption ability }=\frac{\text { Initial dry cell weight }- \text { Remained dry cell weight }}{\text { Surface area } \times \text { Numbers of chitosan gel beads }}
$$

\section{2) Cell desorption}

Five $\mathrm{ml}$ of the seed culture was inoculated into $100 \mathrm{ml}$ of CM medium containing $1 \%$ glucose and $10 \mathrm{ml}$ of photo-crosslinked resin gel beads, ENTG-3800. The cultures were incubated at $30^{\circ} \mathrm{C}$ and 100 strokes/min for $24 \mathrm{~h}$. The beads were washed twice with sterile distilled water and placed in $100 \mathrm{ml}$ of $0.5 \%$ Triton $\mathrm{X}-100,1 \%$ Triton $\mathrm{X}-100$, or $0.5 \%$ Tween 80 . All the flasks were incubated at $30^{\circ} \mathrm{C}$ and 500 or $800 \mathrm{rpm}$. Absorbance was measured in the time interval as previously described.

\section{Cell viability after irradiation with near-ultraviolet light}

The cell suspension was prepared as stated in the section on the preparation of cell suspension. Four ml of cell suspension was spread on a sterile glass plate and irradiated with near-ultraviolet light. The cell suspension was then diluted in series and cultivated on CM agar medium containing $1 \%$ glucose and $1.5 \%$ agar (Nacalai Tesque, Inc., Kyoto, Japan). The experiment was carried out in triplicate.

\section{RESULTS}

\section{Nisin $\mathbf{Z}$ production by cells entrapped with natural materials}

From the results of the subculture, free cells showed an average cell growth of about $1.42 \mathrm{~g} / l$, average lactate about $30.3 \mathrm{~g} /$, and average nisin $\mathrm{Z}$ about $1810 \mathrm{AU} / \mathrm{ml}$ (Fig. 1). Most of the cells entrapped in natural materials showed lower average nisin $Z$ production than the free cells (Fig. 2). Among natural materials tested, agar provided almost the same nisin $\mathrm{Z}$ productivity as the free cells. All of the immobilized cells had low activity during the first incubation, but their activities increased in the subsequent incubations (Fig. 2). However, cell leakage from all of the natural materials was almost equal to the growth of free cells throughout the repeated cultivation. Long-term application of natural materials was limited by the instability of the gel, which was especially obvious in calcium alginate and $\kappa$-carrageenan. Similar results were reported by Uchiyama et al. (1994). Figure 3 shows nisin yield based on carbon source consumption. No natural materials showed higher nisin yield than free cells. Among natural materials, agar gave the best results. 


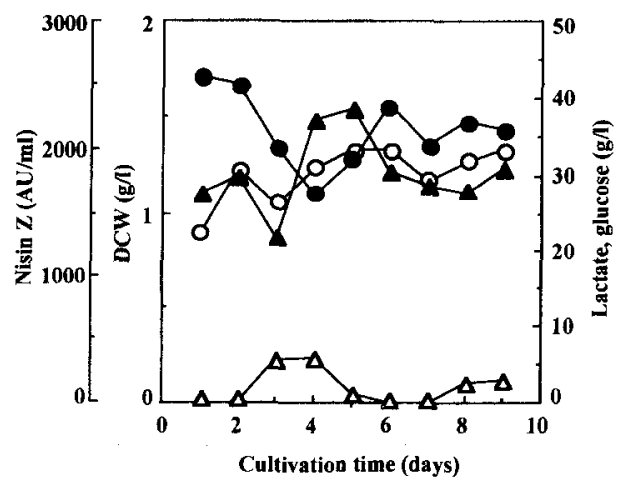

Fig. 1. Cell growth, lactic acid and nisin $\mathrm{Z}$ production in subcultivation of Lactococcus lactis IO-1. The cultivation was done in CM medium supplemented with $4 \%$ glucose and $2 \% \quad \mathrm{CaCO}_{3}$ at $30^{\circ} \mathrm{C}$ and 100 strokes/min for $24 \mathrm{~h}$.

Symbols: Dry cell weight (DCW) $(\mathbf{O})$, nisin $\mathrm{Z}(\mathrm{O})$, lactate $(\boldsymbol{\Delta})$, glucose $(\triangle)$
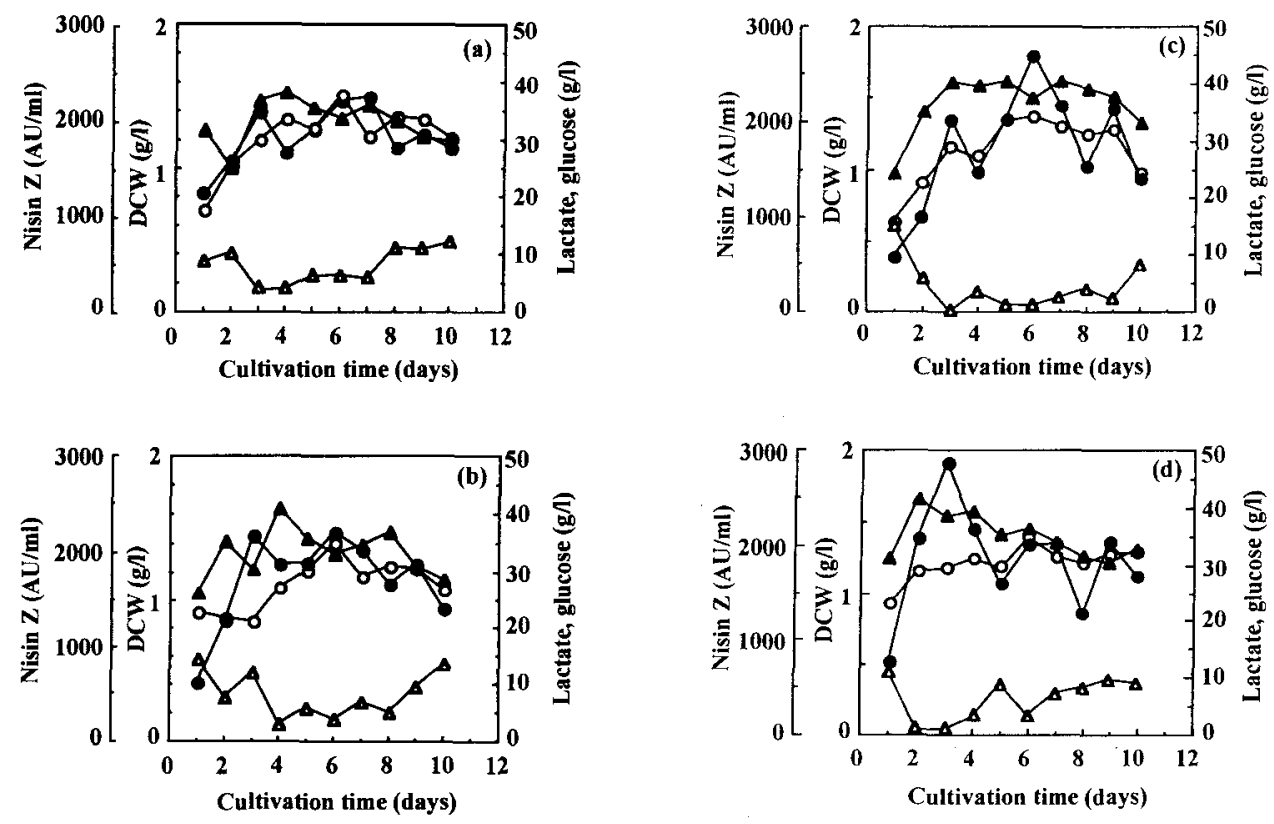

Fig. 2. Nisin Z production in repeated use of Lactococcus lactis $\mathrm{IO}-1$ cells entrapped in natural materials. (a) agar, (b) agarose, (c) calcium alginate, (d) $\kappa$-carrageenan. Each cultivation was carried out for $24 \mathrm{~h}$ at $30^{\circ} \mathrm{C}$ in $100 \mathrm{ml}$ of $\mathrm{CM}$ medium with $5 \%$ glucose and $2.5 \% \mathrm{CaCO}_{3}$.

Symbols: Dry cell weight (DCW) of the cells leaked from gels (O), nisin Z (O), lactate (A), glucose $(\triangle)$ 


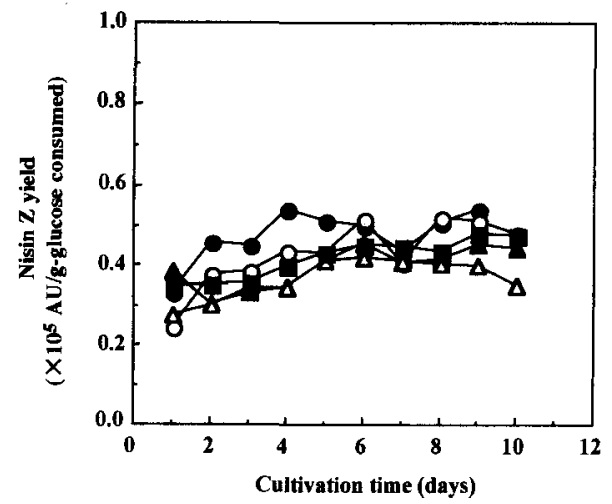

Fig. 3. Nisin $\mathrm{Z}$ yield of free Lactococcus lactis $\mathrm{IO}-1$ cells and the cells entrapped in natural materials.

Symbols: Free cells $(\boldsymbol{O})$, agar $(\bigcirc)$, agarose $(\boldsymbol{\Delta})$ calcium alginate $(\Delta)$, $\kappa$-carrageenan (

\section{Nisin $Z$ production by cells entrapped with synthetic materials}

Synthetic materials used in this experiment were photo-crosslinkable resin prepolymers and urethane prepolymers. The cells entrapped with photo-crosslinkable resin gave low lactate and nisin $\mathrm{Z}$ production, which might result from the low growth of the cells in the gels (Figs. 4a-c). Actually, cell leakage from the gels was less than that from natural materials as previously described. Furthermore, there was a large amount of carbon source left after each cultivation.

In the immobilization of cells with photo-crosslinkable resin prepolymers, it is necessary to illuminate the cell suspension with near-ultraviolet light for $3 \mathrm{~min}$ as described in Materials and Methods. Figure 5 shows the effect of the near-ultraviolet light on IO-1 cells. L. lactis IO- 1 cells were affected by the near-ultraviolet light, which was dependent on the irradiation time. Irradiation for 3 and $5 \mathrm{~min}$ decreased cell concentration about $16 \%$ and $25 \%$, respectively.

Lactate and nisin Z produced by urethane polymer-immobilized cells were nearly equal to those by free cells (Figs. $4 \mathrm{~d}, \mathrm{e}$ ). However, the quantity of cells leaked from the urethane gels was as much as in free cells. Nisin yield based on glucose consumption was slightly higher with ENTP-4000 and PU-3 than the others (Fig. 6). The cells entrapped in ENTP-4000 produced low nisin Z, whereas the nisin yield was high because the low growth rate of the cells contributed to low glucose consumption. Among the synthetic materials tested, PU-3 exhibited the best nisin $\mathrm{Z}$ production, and the fermentation could run longer than 10 days without gel instability. 

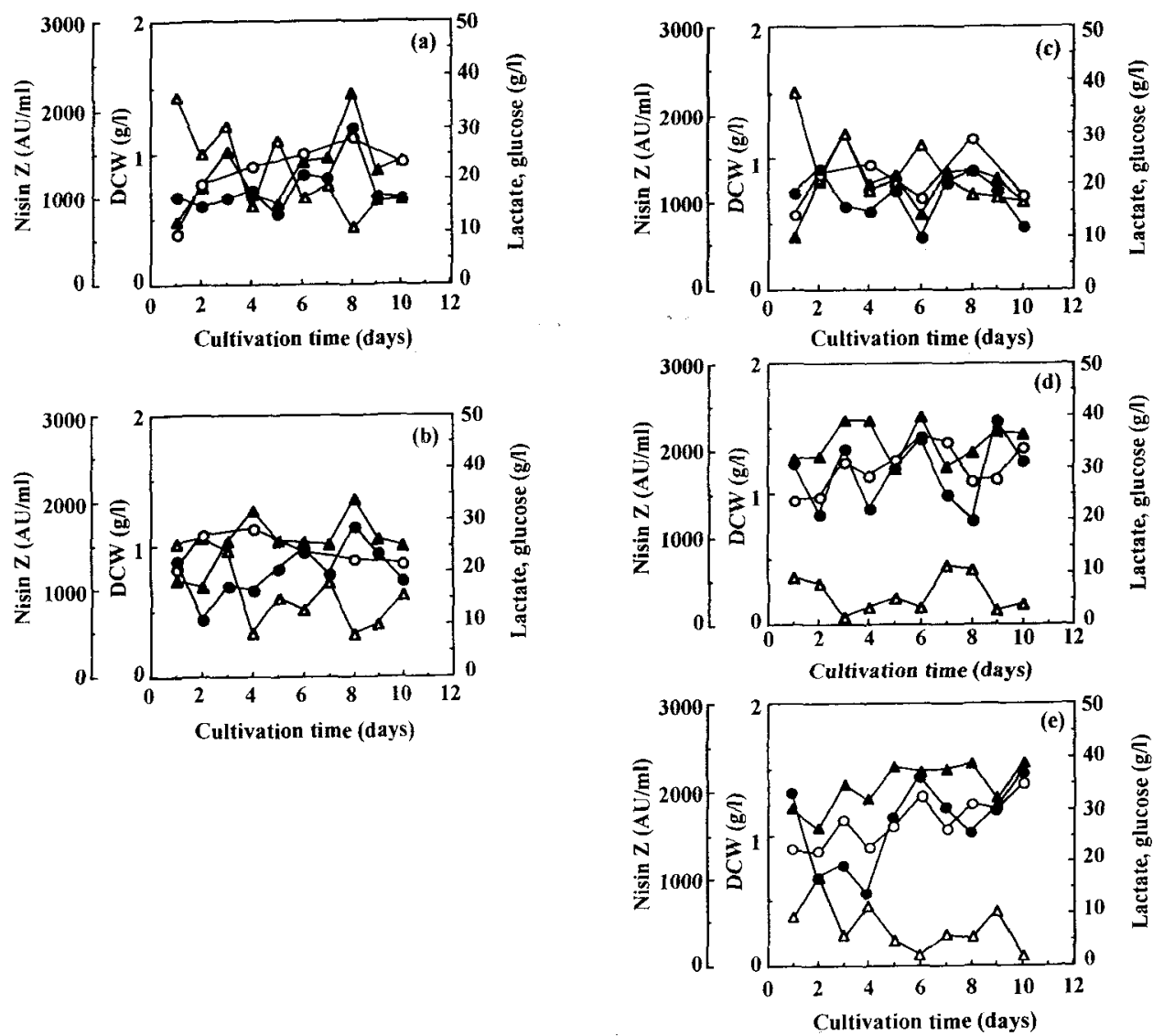

Fig. 4. Nisin $\mathrm{Z}$ production in repeated use of Lactococcus lactis $1 \mathrm{O}-1$ cells entrapped with synthetic materials. (a) ENT-3400, (b) ENTG-3800, (c) ENTP-4000, (d) PU-3, (e) PU-6. Each cultivation was carried out for $24 \mathrm{~h}$ at $30^{\circ} \mathrm{C}$ in $100 \mathrm{ml}$ of $\mathrm{CM}$ medium with $5 \%$ glucose and $2.5 \%$ $\mathrm{CaCO}_{3}$.

Symbols: Dry cell weight (DCW) of the cells leaked from gels $(\mathbf{O})$, nisin Z $(\bigcirc)$, lactate $(\mathbf{A})$, glucose $(\triangle)$ 


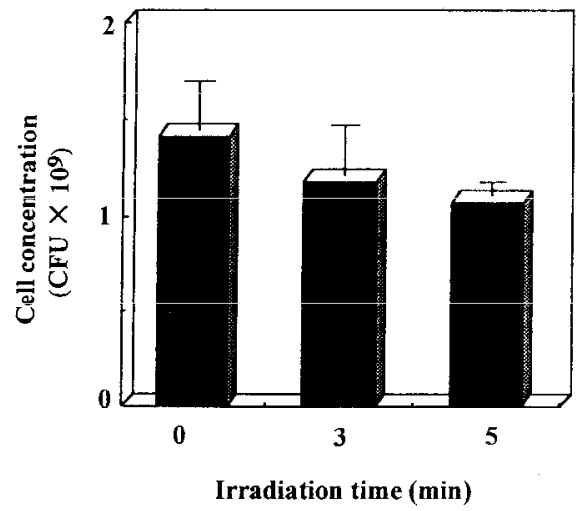

Fig. 5. Effect of near-ultraviolet light on Lactococcus lactis IO-1 cells. Each bar showed the mean $\pm \mathrm{SE}$ which were $0.27,0.24$ and 0.11 for the irradiation time 0,3 and $5 \mathrm{~min}$, respectively.

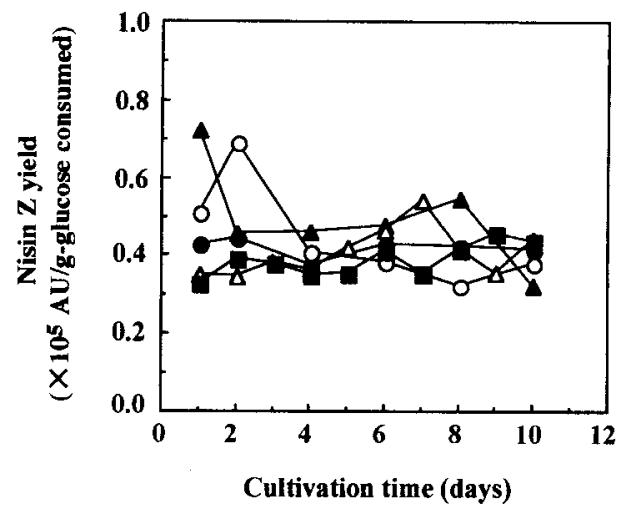

Fig. 6. Nisin Z yield of Lactococcus lactis IO-1 cells entrapped in synthetic materials.

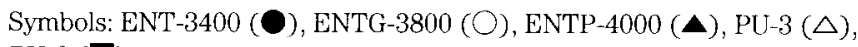
PU-6 


\section{Nisin $\mathbf{Z}$ production by the cells adsorbed on porous chitosan beads}

The adsorption technique was tried to improve the improper diffusion of nutrients through the cell-support materials. The synthetic and chemically modified materials were chosen because of their operational stability. The material used were porous chitosan beads and photo-crosslinked resin gel beads. Figure 7 shows the cell adsorption ability of the porous chitosan beads. Chitopearl HP-2520 was found to be the best support material among the porous chitosan beads. Chitopearl HP-2520 and Chitopearl HP-3520 adsorbed almost all the cells in the cell suspension within $24 \mathrm{~h}$ under the conditions described in Materials and Methods. Thus, Chitopearl type 2500 and type 3500 were selected in the subsequent experiment. Nisin Z production in the repeated use of Chitopearl-adsorbed $L$. lactis IO-1 cells is shown in Fig. 8. Nisin Z production was accompanied by the cells leaked from Chitopearl type 2500 over the range of 2000-4100 AU/ml (Figs. 8a-c). Lactate was stably produced in the range of $27-35 \mathrm{~g} / l$. On the other hand, nisin $\mathrm{Z}$
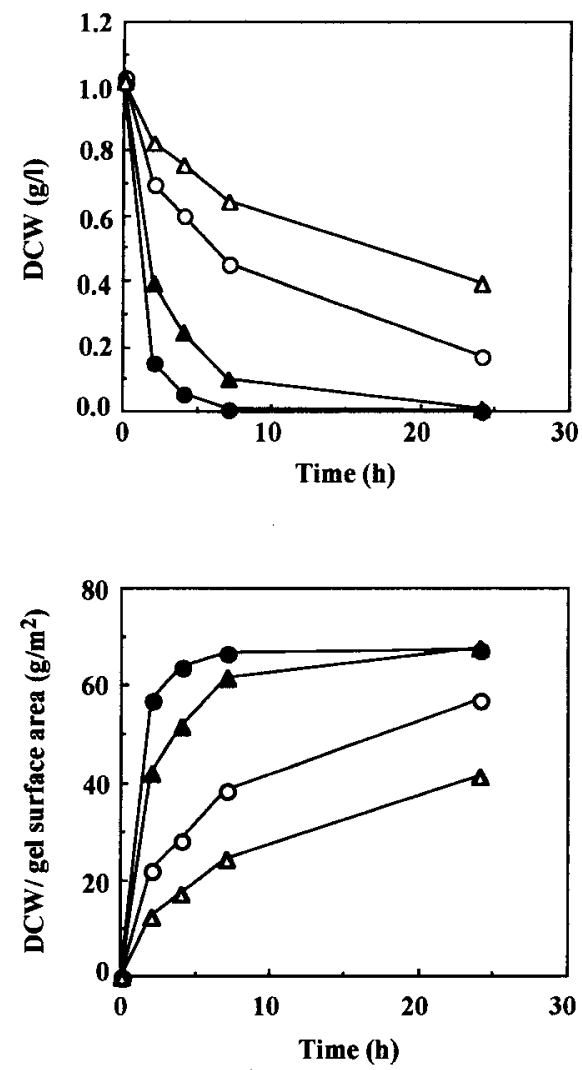

Fig. 7. Comparison of adsorption ability between porous chitosan gel beads. The experimental conditions are shown in Materials and Methods.

Symbols: Chitopearl HP-2520 (O

, Chitopearl HP-3520

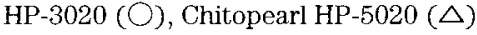



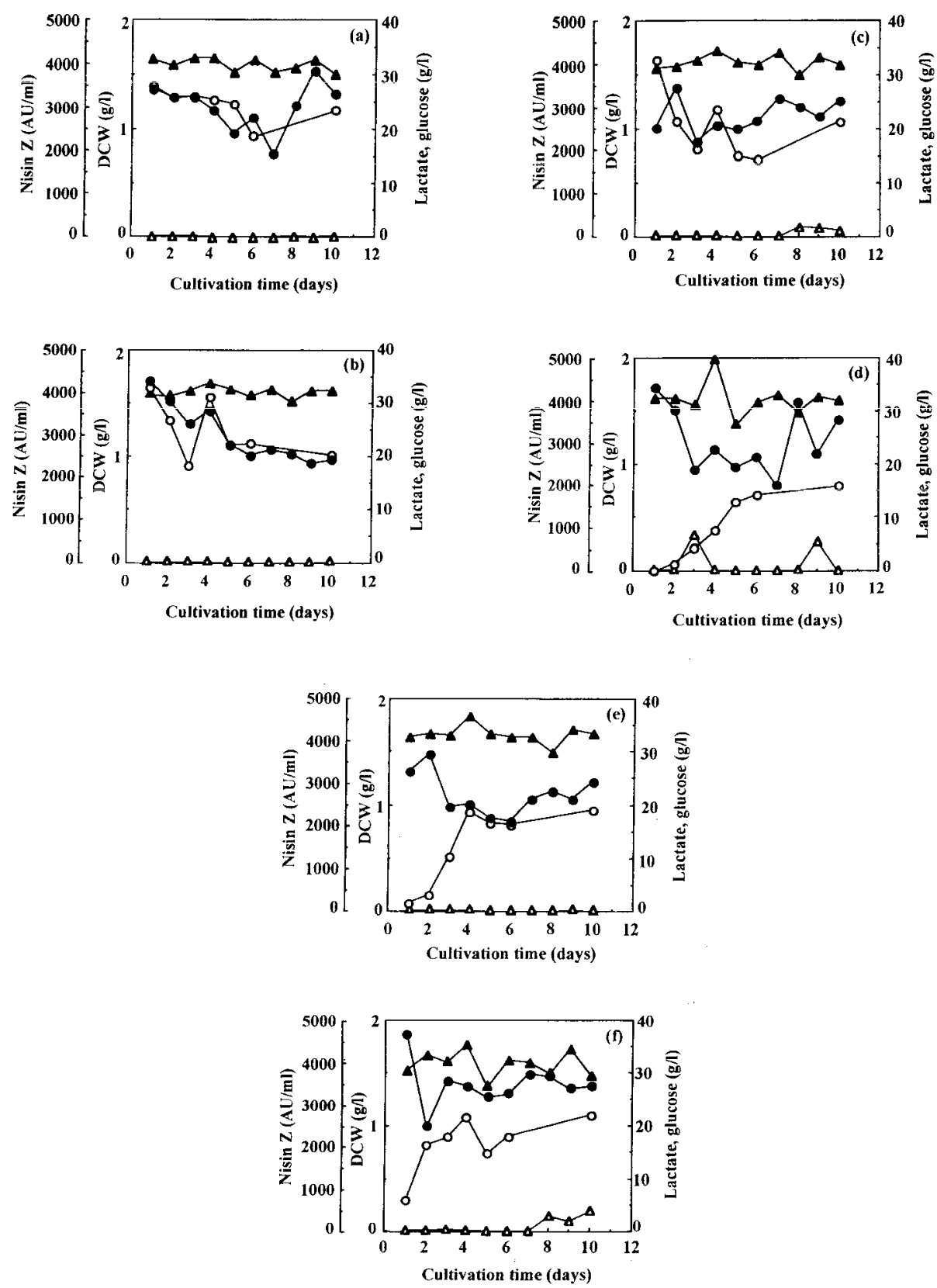

Fig. 8. Nisin Z production in repeated use of Lactococcus lactis IO-1 cells adsorbed on porous chitosan gel beads. (a) Chitopearl SH-2503, (b) Chitopearl SH-2510, (c) Chitopearl HP-2520, (d) Chitopearl SH-3503, (e) Chitopearl SH-3510 and (f) Chitopearl HP-3520. Each cultivation was carried out for $24 \mathrm{~h}$ at $30^{\circ} \mathrm{C}$ in $100 \mathrm{ml}$ of $\mathrm{CM}$ medium with $4 \%$ glucose and $2 \% \mathrm{CaCO}_{3}$.

Symbols: Dry cell weight (DCW) of the cells leaked from gels $(\mathbf{O})$, nisin Z $(\mathrm{O})$, lactate $(\mathbf{\Delta})$, glucose $(\Delta)$ 


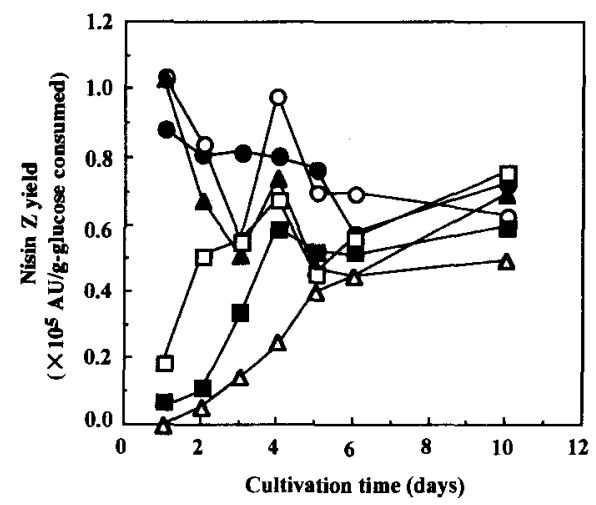

Fig. 9. Nisin Z yield Lactococcus lactis IO-1 cells adsorbed on porous chitosan beads.

Symbols: Chitopearl HP-2503 (O), Chitopearl SH-2510 (O), Chitopearl

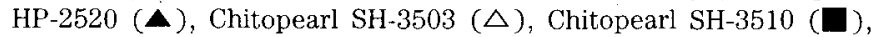
Chitopearl HP-3520 (口)

production was very low in the first cultivation of the cells adsorbed on Chitopearl type 3500. However, they exhibited lactate production and cell leakage similar to those in the Chitopearl type 2500 (Figs. 8d-f). Nisin Z produced was increased in the subsequent cultivation. Nisin Z yield was in the same pattern as nisin Z production (Fig. 9). Chitopearl type 3500 showed lower nisin Z yield than Chitopearl type 2500 . However, the nisin Z yield from Chitopearl type 2500 decreased with an increase in cultivation time.

\section{Nisin $Z$ production by the cells adsorbed on photo-crosslinked resin gel beads}

The photo-crosslinked resin gel beads used were ENT-2000, VGE-112, and ENTG3800, in order of hydrophilicity. The results of the immobilized cells are shown in Fig. 10. The quantity of the cells leaked from the gel beads was great during the first cultivation and decreased in the subsequent cultivation. Among these beads, VGE-112 showed the highest lactate production, while ENTG-3800 showed the lowest. Each nisin Z production was gradually increased with an increase in cultivation time (Fig. 10). At the ninth and tenth cultivation with ENT-2000-adsorbed cells, nisin Z activity was observed to decrease. Nisin $\mathrm{Z}$ yield also increased with increasing cultivation time, similarly to nisin $\mathrm{Z}$ production (Fig. 11).

Among all the materials tested, thus, ENTG-3800 could be the best cell-immobilizing support in continuous fermentation because of the following two reasons: 1 . low production of lactate as an inhibitor of cell growth, and 2. high nisin Z productivity which tended to increase with an increase in cultivation time.

The cell-loading capacity of ENTG-3800 was examined according to the procedure described in Materials and Methods. The results of cells desorbed from the gel beads under the several conditions are shown in Fig. 12. The higher cell desorption was achieved with an increase in detergent concentration. Cells were hardly desorbed from 

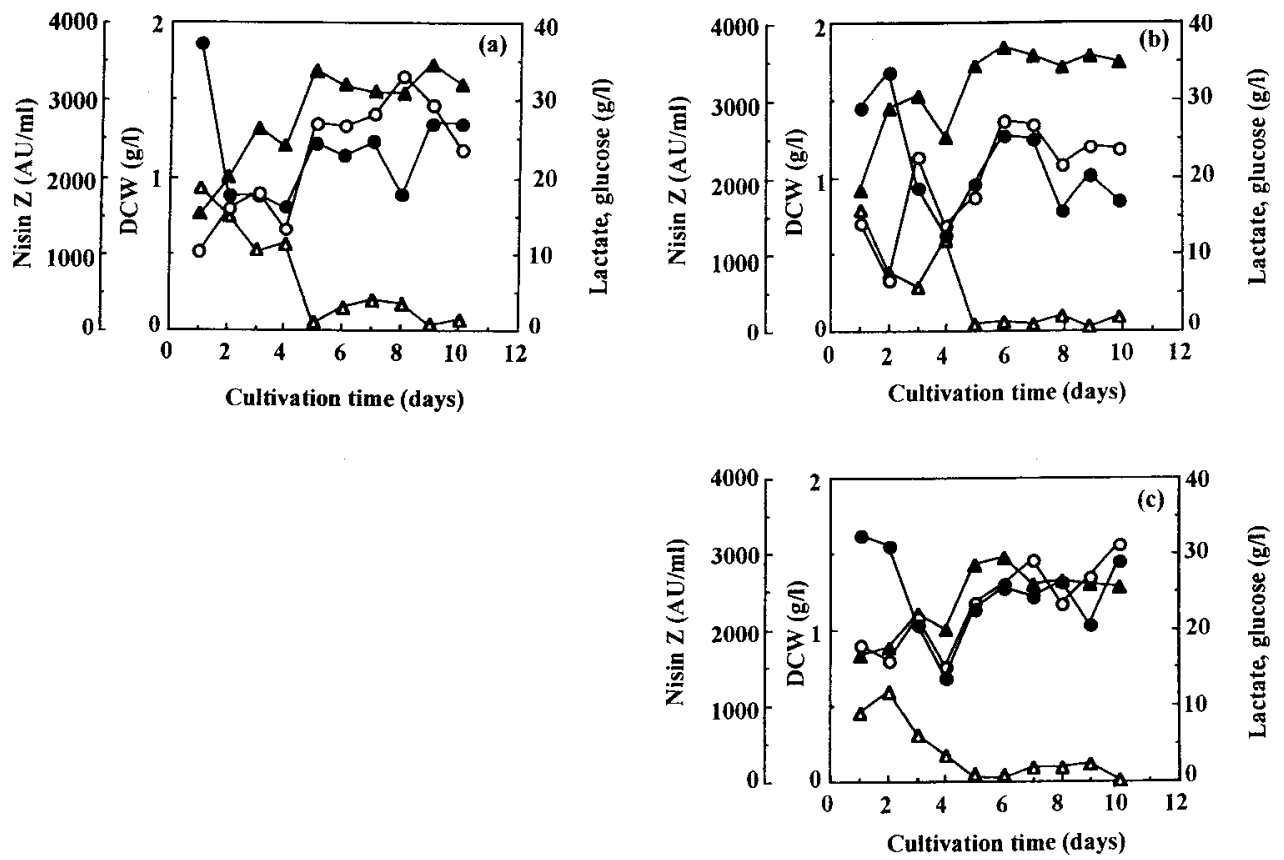

Fig. 10. Nisin Z production in repeated use of Lactococcus lactis IO-1 cells adsorbed on synthetic photo-crosslinked resin gel beads. (a) ENT-2000, (b) VGE-112, (c) ENTG-3800. Each cultivation was carried out for $24 \mathrm{~h}$ at $30^{\circ} \mathrm{C}$ in $100 \mathrm{ml}$ of $\mathrm{CM}$ medium with $4 \%$ glucose and $2 \%$ $\mathrm{CaCO}_{3}$.

Symbols: Dry cell weight (DCW) of the cells leaked from the gels $(\mathbf{O})$, nisin $\mathrm{Z}(\mathrm{O})$, lactate $(\Delta)$, glucose $(\triangle)$

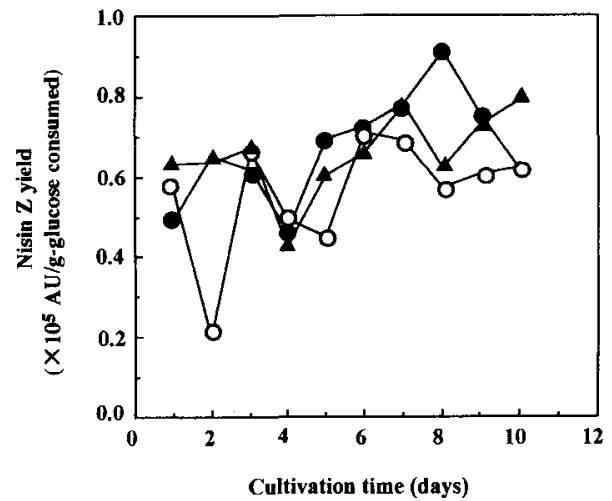

Fig. 11. Nisin Z yield of Lactococcus lactis IO-1 cells adsorbed on photocrosslinked resin gel beads.

Symbols: ENT-2000 (O), VGE-112 (O), ENTG-3800 (A) 


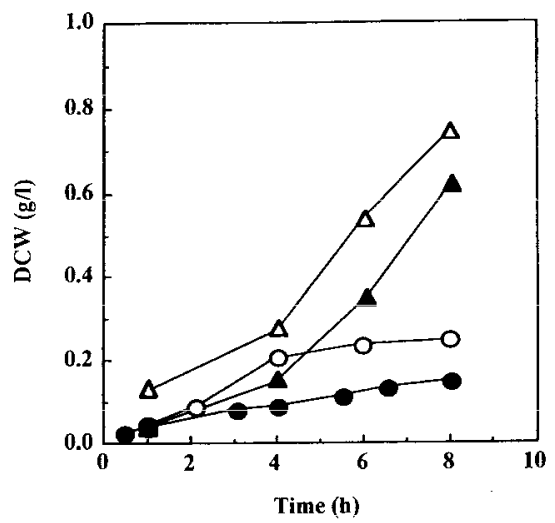

Fig. 12. Desorption of Lactococcus lactis IO-1 cells from photo-crosslinked resin gel beads, ENTG-3800. The experimental conditions are described in Materials and Methods.

Symbols: (O) in $0.5 \%$ Triton X-100 solution at $800 \mathrm{rpm}$

(O) in $1.0 \%$ Triton $X-100$ solution at $800 \mathrm{rpm}$,

(A) in $0.5 \%$ Tween 80 solution at $500 \mathrm{rpm}$,

$(\triangle)$ in $0.5 \%$ Tween 80 solution at $800 \mathrm{rpm}$

the gel without any detergent (data not shown). An increase in agitation speed resulted in an increase in cell desorption. Tween 80 showed higher cell-desorbing activity than Triton X-100. Thus viable cells of $L$. lactis IO-1 are tightly adsorbed on ENTG-3800. The cell-loading capacity of ENTG-3800 was calculated to be greater than $48 \mathrm{~g} / \mathrm{m}^{2}$. Furthermore, this type of gel bead can be regenerated under the previously described conditions where no cells were desorbed from any Chitopearl.

\section{DISCUSSION}

The limitation of nutrient diffusion through the gel and the permeability of the products out of the gel caused the immobilized cells to grow slower than free cells. This led to the lower nisin $\mathrm{Z}$ productivity of the immobilized cells during the first incubation. These problems affected entrapped types more than adsorbed types. Moreover, the longterm application of natural materials such as calcium alginate was limited because of the instability of the gels.

During cell entrapment with photo-crosslinkable resin prepolymers, $L$. lactis IO-1 was damaged by near-ultraviolet light. The cell concentration was decreased 16 and $25 \%$ after the culture was exposed to the light for 3 and $5 \mathrm{~min}$, respectively (Fig. 5). These kinds of immobilized cells showed low glucose consumption and, consequently, low nisin Z productivity (Fig. 4). Probably due to slow cell growth in the gel, the average cell leakage was less than the others. Sensitivity to near-ultraviolet light during cell entrapment with the prepolymers is dependent on the strains. Wakao et al. (1994) reported that the iron oxidation activity of Thiobacillus ferrooxidans was completely inhibited during the 
course of immobilization with the prepolymers. The negative effects of this prepolymer method on immobilized bacterial cells were also reported by Takashima et al. (1987) and Uchiyama et al. (1994). On the other hand, various kinds of microbial cells such as bacteria, yeasts and fungi could be applied to bioconversion and fermentation in the states of living and growing using the prepolymer methods (Iida, 1992; Fukui et al., 1987; Fukui and Tanaka, 1989).

Among various kinds of porous chitosan beads, Chitopearl HP-3020 and HP-5020 did not adsorb as many cells as Chitopearl HP-2520 and HP-3520 (Fig. 7). The cells adsorbed on Chitopearl 2500 type materials showed a high level of nisin $Z$ production. However, nisin Z production was gradually decreased with repeated cultivation (Figs. 8a-c). The decrease in nisin $\mathrm{Z}$ activity during the repeated use might be caused by sloughing of the microbial layer from the surface of chitosan beads as stated by Mori et al. (1992). The binding mode of Chitopearl type 3500 was hydrophobic; hence, nisin $\mathrm{Z}$ should be easily adsorbed along the repeated batch fermentation (Figs. 8d-f). Nisin was allowed to adsorb on silanized silica surfaces for use as a food grade antimicrobial agent on food contact surfaces (Bower et $a l ., 1995$ ). Chitopearl SH-3503 with 0.3-mm particle sizes showed lower nisin Z production than Chitopearl SH-3510 and HP-3520 whose particle sizes are $1.0 \mathrm{~mm}$ and $2.0 \mathrm{~mm}$, respectively. Thus, Chitopearl $\mathrm{SH}-3503$ has a greater surface area for nisin adsorption than Chitopearl SH-3510 and HP-3520. Nisin Z activity in the broth of Chitopearl type 3500-adsorbed cells increased with an increase in cultivation time because the materials were gradually saturated with the nisin Z produced (Figs. 8d-f).

Photo-crosslinked resin gel beads as new cell-adsorbing support materials have several advantages as follows: During the course of immobilization, the cells are not exposed to near-ultraviolet light which is occastionally responsible for cell damage. The gel beads are given the desired properties through the gel formation process prior to cell adsorption. The pore size of the gel can be controlled by the chain length of the composed prepolymer. The hydrophilicity and hydrophobicity of gel can be obtained by choosing and mixing polyethylene glycol and polypropylene glycol as the main skeleton of the prepolymers. Selecting proper functional groups resulted in the desired ionic property of the beads.

Among the cell-immobilizing supports tested, ENTG-3800 was the best material for nisin Z production. ENTG-3800 has a higher gel strength than natural support materials, which could be used for long-term application. During the repeated use of ENTG-3800adsorbed cells, low lactate and high level of nisin $Z$ were produced (Fig. 10c). Although high nisin $Z$ production was observed in the cultivation with porous chitosan beads, the nisin $Z$ activity was on the same level as that by ENTG-3800 at the sixth cultivation. Nisin $\mathrm{Z}$ production by the cells adsorbed on ENTG-3800 gradually increased after the sixth cultivation.

The comparison of nisin Z production between the free cells and ENTG-3800adsorbed cells is shown in Fig. 13. Through repeated cultivation, the concentration of free cells was higher than that of cells leaked from the beads (Fig. 13a). Nevertheless, the adsorbed cell system showed higher nisin $Z$ production than the free cell system. Nisin $\mathrm{Z}$ produced by the adsorbed cell system was increased with an increase in repeated use (Fig. 13b). Nisin Z activity from the free cells was almost constant during the operation. On the other hand, in terms of lactate formation, the immobilized cells were 

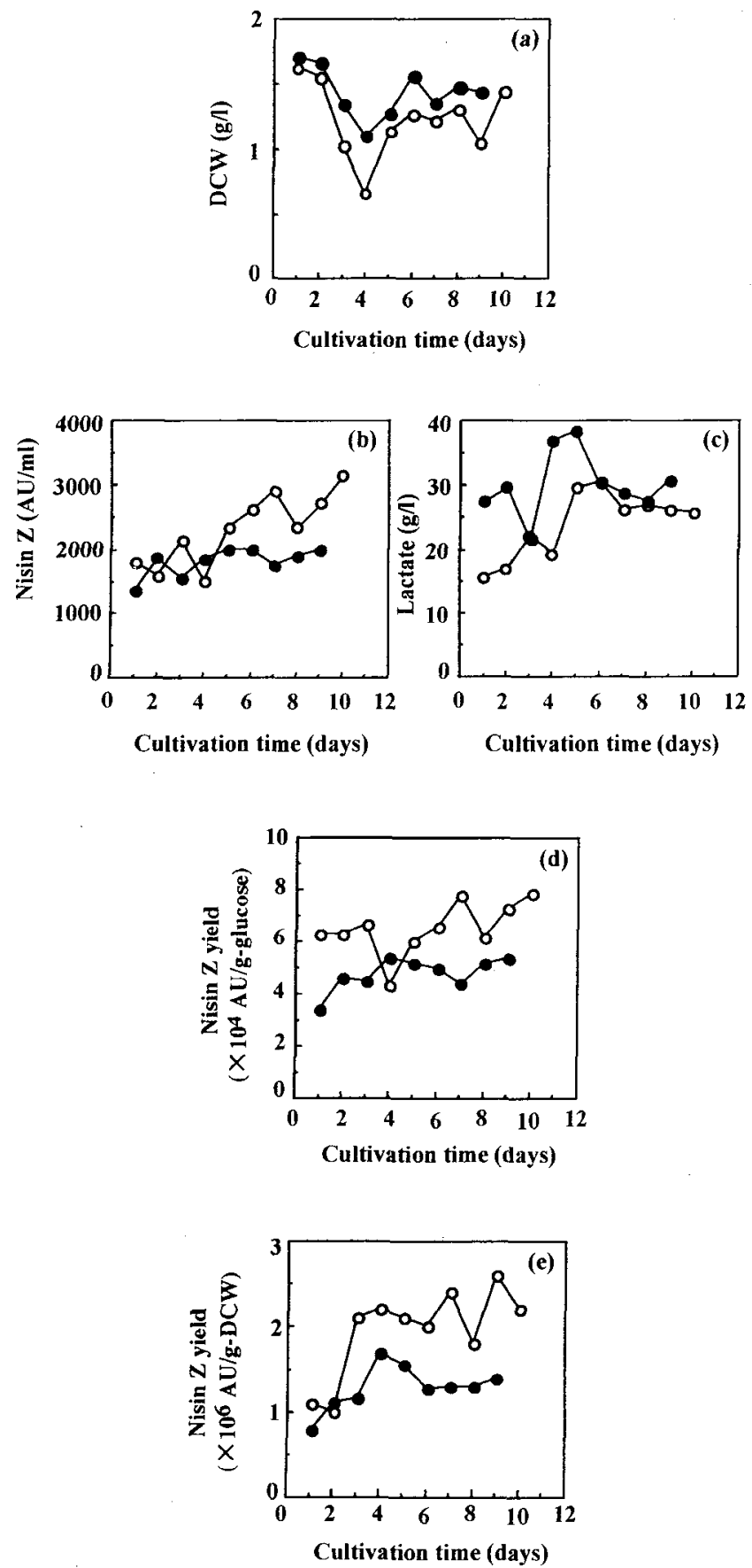

Fig. 13. Comparison between the free cells (closed symbol) and ENTG-3800-adsorbed cells (open symbol). (a) Dry cell weight (DCW) of free or leaked cells in the broth, (b) nisin $Z$ produced, (c) lactate produced, (d) nisin Z yield based on glucose consumption, (e) nisin Z yield based on DCW in the broth. 
observed at a low concentration (Fig. 13c). Nisin Z yields based on glucose consumption and free cell mass in the broth were higher in the immobilized system than in the free cells (Figs. 13d, e). From the results in Fig. 13, ENTG-3800 can, therefore, be presumed to adsorb many more active cells during the repeated use in comparison with that at the initial cultivation. This could be responsible for the increase in nisin $\mathrm{Z}$ production in the repeated cultivation.

The capability to release the adsorbed cells from the gel in the presence of a surfactant suggested the possibility of bead regeneration which could not be performed with any type of Chitopearl. Tween 80 was more suitable than Triton X-100 for cell desorption from ENTG-3800 gel beads as shown in Fig. 12. The agitation speed was another factor that affected the desorption.

\section{ACKNOWLEDGMENT}

The authors are indebted to Fuji Spinning Co., Ltd. and Kansai Paint Co., for their generous supply of the gel materials used in this study.

\section{REFERENCES}

Araya, T., Ishibashi, N. and S. Shimamura 1992 Genetic evidence that Lactococcus lactis JCM 7638 produces a mutated form of nisin. J. Gen. Appl. Microbiol., 38: 271-278

Bower, C. K., Mcquire, J. and M. A. Daeschel 1995 Suppression of Listeria monocytogenes colonization following adsorption to nisin onto silica surfaces. Appl. Environ. Microbiol, 61: 992-997

Boyaval, P. and J. Goulet 1988 Optimal conditions for production of lactic acid from cheese whey permeate by calcium alginate entrapped Lactobacillus helveticus. Enzyme Microb. Technol., 10: 725-728

Cachon, R., Molin, P. and C. Divies 1995 Model of continuous pH-stat stirred tank reactor with Lactococcus lactis ssp. lactis bv. diacetylactis immobilized in calcium alginate gel beads. Biotechnol. Bioeng., 47: 567-574

Chibata, I. 1978 Immobilized Enzymes: Research and Development. Kodansha, Ltd., Tokyo (Japan)

Cho, H. Y., Yousef, A.E. and S.T. Yang 1996 Continuous production of pediocin by immobilized Pediococcus acidilactici $\mathrm{PO} 2$ in a packed-bed bioreactor. Appl. Microbiol. Biotechnol., 45: 589-594

De Vuyst, L. 1994 Nisin production variability between natural Lactococcus lactis subsp. lactis strains. Biotechnol. Lett., 16:287-292

De Vuyst, L. and E. J. Vandamme 1992 Influence of the carbon source on nisin production in Lactococcus lactis subsp. lactis batch fermentations. J. Gen. Microbiol., 138: 571-578

De Vuyst, L. and E. J. Vandamme 1993 Influence of the phosphorus and nitrogen source on nisin production in Lactococcus lactis subsp. lactis batch fermentations using a complex medium. Appl. Microbiol. Biotechnol., 40: 12-22

Fukui, S., Sonomoto, K. and A. Tanaka 1987 Entrapment of biocatalysts with photo-crosslinkable resin prepolymers and urethane resin prepolymers. In "Method in Enzymology", Vol. 135, ed. by K. Mosbach, Academic Press, Inc., New York, pp. 230-252

Fukui, S. and A. Tanaka 1989 Application of living microbial cells entrapped with synthetic resin prepolymers. Experientia, 45: 1055-1061

Huang, L., Lacroix, C., Daba, H. and R. E. Simard 1996 Pediocin 5 production and plasmid stability during continuous free and immobilized cell cultures of Pediococcus acidilactici UL5. J. Appl. Bacteriol., 80: $635-644$

Iida, T. 1992 Fuel ethanol production by immobilized yeasts and yeast immobilization. In "Industrial Application of Immobilized Biocatalysts", ed. by A. Tanaka, T. Tosa and T. Kobayashi, Marcel Dekker, Inc., New York, pp. 163-182

Iida, T. $1994 \mathrm{PhD}$. Thesis (Immobilization of biocatalysts with photo-crosslinkable resin prepolymers and 
its application) (In Japanese)

Iida, T., Izumida, H., Akagi, Y. and M. Sakamoto 1993a Continuous ethanol fermentation in molasses medium using Zymomonas mobilis immobilized in photo-crosslinkable resin gels. J. Ferment. Bioeng., 75: $32-35$

Iida, T., Sakamoto M., Izumida, H. and Y. Akagi 1993b Characteristics of Zymomonas mobilis immobilized by photo-crosslinkable resin in ethanol fermentation. J.Ferment. Bioeng., 75: 28-31

Ishizaki, A., Osajima, K., Nakamura, K., Kimura, K., Hara, T. and T. Ezaki 1990 Biochemical characterization of Lactococcus lactis IO-1 whose optimum temperature is as high as $37^{\circ} \mathrm{C} . \mathrm{J}$. Gen. Appl. Microbiol., 36: $1-6$

Matsusaki, H., Endo, N., Sonomoto, K. and A. Ishizaki 1996a Lantibiotic nisin Z fermentative production by Lactococcus lactis IO-1: relationship between production of the lantibiotic and lactate and cell growth. Appl. Microbiol. Biotechnol., 45: 36-40

Matsusaki, H., Endo, N., Sonomoto, K. and A. Ishizaki 1996b Development of purification method and identification of a peptide antibiotic produced by Lactococcus lactis IO-1. Food Sci. Technol, Int., 2 157-162

Mehaia, M. A. and M. Cheryan 1987 Immobilization of Lactobacillus bulgaricus in a hollow fiber bioreactor for production of lactic acid from acid whey permeate. Appl. Biochem. Biotechnol., 14: 2127

Mori, A., Tanaka, S., Matsumoto, N. and C. Imai 1992 Vinegar production in a bioreactor with chitosan beads as supports of immobilized bacteria. In "Biochemical Engineering for 2001", ed. by S. Furusaki, I. Endo and R. Matsuno, Springer-Verlag, Heidelberg, pp. 441-443

Nomura, Y., Iwahara, M. and M. Hongo 1987 Lactic acid production by electrodialysis fermentation using immobilized growing cells. Biotechnol. Bioeng., 30: 788-793

Ogbonna, J. C., Amano, Y. and K. Nagamura 1989 Elucidation of optimum condition for immobilization of viable cells in calcium alginate. J. Ferment. Bioeng., 67: 92-96

Ogbonna, J. C., Liu, Y. C., Liu, Y. K. and H. Tanaka 1994 Loofa (Luffa cylindrica) sponge as a carrier for microbial cell immobilization. J. Ferment. Bioeng., 78: 437-442

Pasini, G., Crapisi, A., Lante, A., Curioni, A., Zamorani, A. and P. Spettoli 1995 Evaluation of bacteriocin activity produced in milk by Lactococcus lactis subsp. lactis, immobilized in barium alginate beads. Ann. N. Y. Acad. Sci., 750: 465-468

Takashima, Y., Nakayama, H., Sonomoto, K. and A. Tanaka 1987 Production of daunorubicin by immobilized growing Streptomyces peucetius cells. Appl. Microbiol. Biotechnol., 27: 106-109

Tanaka, H., Matsumura, M. and I. A. Veliky 1984 Diffusion characteristics of substrates in calcium alginate gel beads. Biotechnol. Bioeng., 26: $53-58$

Tanaka, T., Yamamoto, K., Towprayoon, S., Nakajima, H., Sonomoto, K., Yokozeki, K., Kubota, K. and A. Tanaka 1989 Continuous production of L-serine by immobilized growing Corynebacterium glycinophilum cells. Appl. Microbiol. Biotechnol., 30: 564-568

Uchiyama, H., Yagi, O., Oguri, K. and E. Kokufuta 1994 Immobilization of trichloroethylene-degrading bacterium, Methylocystis sp. strain M in different matrices. J. Ferment. Bioeng., 77: 173-177

Wakao, N., Endo, K., Mino, K., Sakurai, Y. and H. Shiota 1994 Immobilization of Thiobacillus ferrooxidans using various polymers as matrix. J. Gen. Appl. Microbiol., 40: 349-358

Wan, J., Hickey, M. W. and M.J. Coventry 1995 Continuous production of bacteriocins, brevicin, nisin, and pediocin using calcium alginate immobilized bacteria. J. Appl. Bacteriol., 79: 671-676

Yamauchi, Y, Okamoto, T., Murayama, H., Nagara, A., Kashihara, T. and K. Nakanishi 1994 Beer brewing using an immobilized yeast bioreactor: Design of an immobilized yeast bioreactor for rapid beer brewing system. J. Ferment. Bioeng., 78: 443-449

Yang, S. T. and Y. Huang 1995 A novel recycle batch immobilized cell bioreactor for propionate production from whey lactose. Biotechnol. Bioeng., 45: 379-386

Zezza, N., Pasini, G., Lombardi, A., Mercenier, A., Spettoti, P., Zamorani, A. and M. P. Nuti 1993 Production of a bacteriocin active on lactate fermenting clostridia by Lactococcus lactis subsp. lactis immobilized in coated alginate beads. J. Dairy Res., 60: 581-591 